\title{
To Open the Mouth, to Show the Tongue: Anthropophagic Gestures in
} Brazilian Art

\author{
de Oliveira, Eduardo Jorge ; Masseno Viana, Andre Luiz
}

\begin{abstract}
This essay seeks to articulate a detailed reading through two anatomical selections -the mouth and tongue - in Brazilian art from the end of the 1960s. The reading is part of a shift in the matrix of Oswald de Andrade's "Anthropophagic Manifesto," originally published in the Revista de Antropofagia in 1928, whose interpretations spread in Brazil during the second half of the 20th century. This study mobilises elements of the manifesto and its resonance in the works of artists such as Anna Maria Maiolino, Lygia Pape, Paulo Bruscky, and Lenora de Barros.
\end{abstract}

DOI: https://doi.org/10.53397/hunnu.jflc.202102013

Posted at the Zurich Open Repository and Archive, University of Zurich

ZORA URL: https://doi.org/10.5167/uzh-212257

Journal Article

Published Version

Originally published at:

de Oliveira, Eduardo Jorge; Masseno Viana, Andre Luiz (2021). To Open the Mouth, to Show the Tongue: Anthropophagic Gestures in Brazilian Art. Journal of Foreign Languages and Cultures:143-151. DOI: https://doi.org/10.53397/hunnu.jflc.202102013 


\title{
To Open the Mouth, to Show the Tongue: Anthropophagic Gestures in Brazilian Art
}

$\odot$ Eduardo Jorge de Oliveira, André Masseno

University of Zurich

\begin{abstract}
This essay seeks to articulate a detailed reading through two anatomical selections the mouth and tongue - in Brazilian art from the end of the 1960s. The reading is part of a shift in the matrix of Oswald de Andrade's "Anthropophagic Manifesto," originally published in the Revista de Antropofagia in 1928, whose interpretations spread in Brazil during the second half of the 20th century. This study mobilises elements of the manifesto and its resonance in the works of artists such as Anna Maria Maiolino, Lygia Pape, Paulo Bruscky, and Lenora de Barros.
\end{abstract}

Keywords: mouth, tongue, Anthropophagic Manifesto, Oswald de Andrade, Brazilian art

CLC: 1777 Document Code: A Article ID: 2096-4374(2021)02-0143-09

Doi: 10.53397/hunnu.jflc.202102013

\section{General Considerations on Anthropophagy}

"Morte e vida das hypoteses. Da equação eu parte do Kosmos ao axioma Kosmos parte do eu. Subsistência. Conhecimento. Antropofagia."

Oswald de Andrade, "Anthropophagic Manifesto"

The "Anthropophagic Manifesto" ("Manifesto Antropófago") by Oswald de Andrade is an inexhaustible source of readings, from which new hypotheses can always be found to interpret what has come to be called anthropophagic culture in Brazil. The hypotheses die and are born in a flux which considers the relation, in terms of equation and axiom, between the "self" and the "cosmos." Always open to movements of renewal, from the manifesto one can move to a psychology. According to Andrade in "The Anthropophagic Psychology" ("A psicologia antropofágica"), published in 1929, anthropophagy would be a movement of (re)vitalisation of Brazil, "a revolution of principles, of the script, of identification" (50). The "Anthropophagic Manifesto" therefore expresses a desire to rewrite local history, and envisages new paths of artistic production and reading of the Brazilian context. Anthropophagy seeks a kind of local knowledge/taste (or saber/sabor in Portuguese), while critically reviewing colonial power and imported knowledge (Jackson 430). There is, therefore, an emphasis on a local culture whose cosmopolitanism is distinct from the parameters preached by the European avantgarde with its manifestos because, as Kenneth David Jackson rightly recalls, while "the manifestos 
of the European avant-garde intended to modernise society in the service of certain utopian ends," Oswaldian Anthropophagy emerged to argue that "Freud [was] Brazilian and utopia [had] already [been] achieved" (Jackson 436). Furthermore, the "Anthropophagic Manifesto" distances itself from any sort of genealogical or essentialist script towards a Brazilian cultural identity. We can even think of the Oswaldian manifesto as a practical exercise of appropriation of cultural elements of the 1920s, as suggested by João Cezar de Castro Rocha ("Uma teoria” 654). The reflexive power of anthropophagy reaches beyond the Brazilian modernist context and local intellectuality, which has allowed for rereadings that go beyond the national—some successful, others more in tune with the banquet demanded by the diners of neoliberal capitalism. In this sense, anthropophagy can be considered a kind of "cultural operation" (660) not necessarily identified by national criteria and beyond its historical time.

In the last quarter of the $1960 \mathrm{~s}$, precisely on the occasion of the 40th anniversary of Anthropophagy Manifesto, anticipated by the recuperation of the Oswaldian oeuvre by Haroldo de Campos in the second half of the decade, some artistic works revisited the Oswaldian legacy. The "Anthropophagic Manifesto" resurfaced in favor of a critically ironic look at a Brazil dominated by a civil-military dictatorship keen to forge a univocal image of a typically Brazilian nation and culture. Anthropophagy would attract the attention of artists who flirted with other cultural realities and opposed the purist and xenophobic discourse disseminated through official government channels. Artists such as theatre director José Celso Martinez Corrêa, with the staging of Andrade's play The Candle King (O Rei da Vela), the singer and composer Caetano Veloso, author of the song "Tropicália," and the writer, filmmaker and theatre director José Agrippino de Paula, with the film Hitler the Third Reich (Hitler III Mundo), the play Rite of Wild Love (Rito do Amor Selvagem), and the novel Panamérica - all from 1967-envisioned a Brazil that did not disregard the massive entry of the culture industry into the country, that was global in scope and anthropophagic in outlook.

Firstly, it is important to stress that Brazil of the 1960s and 1970s was a territory of mass landing of products of the foreign culture industry, especially through the consolidation of the multinational phonographic market and television, not to mention the predominance of Hollywood film production, which had been present in Brazil since the middle of the first half of the 20th century. There was a growing accumulation of foreign audiovisual records in Brazil, to the point of generating a problematic "anthropophagy in reverse," that is, the configuration of another historical stage of anthropophagy not exercised by the native anthropophagist, but by a consumer industry on a global scale.

In the case of the Tropicalist movement, for example, anthropophagy contributed to its ironic and sarcastic staging of the incongruities of Brazilian spatiality by placing the monumental and megalomaniac discourse of national modernity side by side with depictions of poverty and local historical and social inequality. The symbolic rewriting of the anthropophagic premise made especially by the musical strand of Tropicalismo came about through an artistic language which put records of mass culture, both local and international, in dialogue with the images that were at times chaotic and hallucinatory, thus seeking new aesthetic strategies to address an environment that was in itself conflictive and irrational. ${ }^{1}$

The anthropophagist of the 1960s and 1970s was therefore left with a few alternatives: to remain doomed to hunger, or to consume that which consumed him. In this sense, cultural agents attuned to the Oswaldian anthropophagic proposal sought an artistic language that was not at all refractory to the world condition of consumption, being inevitably and assumedly consumerist of foreign culture. However, a problem inseparable from the previous one then arose: how to create an artistic language in the tropics that devours others, but without falling back into the reductionist procedure typical of the aforementioned "anthropophagy in reverse," which liquefied the power of the devoured? One 
hypothesis pursued in this article is to identify Anthropophagy as a starting point for new cultural transformations. One of the examples took place in the 1970s, when Augusto de Campos, interviewing Caetano Veloso, asked him what tropicalism was. At the end of his brief reply, the singer summarised: "Tropicalism is a neo-Anthropophagism" (207). Even if the defining framework of the Tropicalist movement is broader, involving other cultural actors, it is worth noting that this reply presents the heart of the matter: Anthropophagy emerges to "die" and "be born," to be culturally redefined, albeit in the form of Tropicalism. What literally occurs is a mutation of which little remains of the anthropophagic ritual recorded by European travellers in the 16th century on the coast of Brazil with the people of Tupi origin. In music, John Harvey wrote that the term "tropicalismo," derived from Hélio Oiticica's Tropicália installation, was used by Os Mutantes:

The members of Os Mutantes were still in their teens when the vanguard composer Rogério Duprat introduced them to Gilberto Gil, founding member of the tropicalismo movement. Gil spoke of the trio to Caetano Veloso, who had not yet become one of Brazil's best known artists. Having already released their eponymous album under the direction of Rogério Duprat, Os Mutantes were enlisted to back the collaborative album Tropicália: ou Panis et Circensis (1968), which became a musical manifesto of the multimedia arts movement of tropicalismo (109).

This is an example of the circulation of the manifesto that, in moving from literature to music, produces a death and birth of the anthropophagic hypothesis, in the sense that the field of devouring has both a mouth-territory and a topographical language.

\section{Mouth-Territory: An Anthropophagic Materialism}

In the field of the visual arts of the 1960s and 1970s, there was a recurrent appeal to the image of the mouth as an organ that can devour and expel everything, that can reprocess and return, in a different way, what was devoured or what could not be swallowed. The mouth is, at times, the locus of the production of meaning stemming from articulated speech, at times it is the space of mutism or silence, babbling, murmuring or even the impossibility of communicating something articulable in the field of language. It is from the mouth that singing comes, that is, an articulation of rhythm independent of words. Related to the protagonism of the mouth, the teeth and tongue appear, both essential to the process of swallowing, where the former grinds what is eaten, and the latter tastes what will be swallowed. These representations are, therefore, legatees of the resurgence of Oswaldian Anthropophagy as a possible ethical-aesthetic script for reinterpreting the internal impasses Brazil was going through at that time. The revisiting of anthropophagy was combined with a greater attention to the body, including its visceral state, as well as to the participatory element and to performance in the artistic and social spheres (Asbury 69-76).

Figurations of the mouth are recurrent in the work of the artist Anna Maria Maiolino of that period. In the works Schhhiii, ANNA and Glu Glu Glu, ${ }^{2}$ all woodcut engravings produced in 1967, the mouth is presented as the producer of language and the pathway of swallowing, but at the same time the target of forced silencing. The three works compose a figurative vocabulary of the mouth in an implicit relationship with the political oppression that prevailed in Brazil under the weight of the dictatorship, where naming, that is, producing meanings and languages, feeding oneself and being silent/silenced were suspicious and surveilled actions. The mouth is a hollow space and constitutive of 
an anthropomorphic figure practically devoid of a neck, with the skull directly connected to the torso, allowing us to glimpse it as a later relative of Tarsila do Amaral's Abaporu, although Maiolino's figure is less curvilinear, cut at the height of the trunk and, unlike Abaporu, has a face and mouth. ${ }^{3}$ Abaporu, according to Gonzalo Aguilar's shrewd analysis (37), is an exercise in stripping away the signs of identity in order to build a new human, and which, by presenting an intense relationship between the living and the landscape, allows us to "affirm that it is about the portrait of the human who eats" (44). Even without the representation of the mouth, the image is in possession of a devouring action, and also inherits from Tarsila the dimension of the mouth present in a 1923 painting, A Negra, whose mouth is an enlarged and distorted coffee bean. This pre-Abaporu image concerns the anatomical limits of a single large breast, whose curves connect directly with the mouth, that makes the painting an immanent action of superimpositions. It is only fitting to point out that with this painting, Tarsila do Amaral anticipates elements of the 1924 "Pau-Brasil Manifesto" just as Abaporu does with the "Anthropophagic Manifesto" of 1928. Along this imagetic lineage of Tarsila do Amaral, Anna Maria Maiolino's woodcuts seem to create a split between the figure and its surroundings, with the mouth being a territory of a discourse-to-be, capable of devouring both the identity mark as well as the silencing imposed by censorship at the time. Eating is a discourse that extrapolates a hunger for discursive production faced with the authoritarianism that is currently shoved down the throat. In another work, authoritarianism is diluted in family harmony. In Por um Fio (By a Thread), ${ }^{4}$ from 1976/2006, the artist brings together three generations, herself, her mother and her daughter. The three are joined by threads of spaghetti that not only demarcate Maiolino's Italian origin, but also recover the family act of eating, that is, the shared memory of Sunday spaghetti of many Brazilian families. However, the ambiguity is in the title, as "by a thread" exalts the fragility of the situation which can be interrupted at any moment. In the contrast between the title and the image there remains a portrayal of the time: the threat of disappearance of an artistic work if considered suspicious by the censorship regime.

A conflictive operation between the internal and external specialities of the mouth, between swallowing and expelling, is exemplified in Maiolino's film In-Out (Antropofagia), shot on Super 8 and dated 1973-1974. ${ }^{5}$ For a little over eight minutes, two mouths, one female and one male, display their teeth and explore mouth and lips as if in the process of articulating a speech still inaudible to the audience. The differences in the tonicity of the mouth muscles are demarcated by the changing colour of the lips. At the same time, a heterodiegetic path composed of inarticulate and ambiguous vocal expressions - moaning of pleasure or displeasure? Pre-language or interrupted language? - runs through the entire length of the video. In addition, the mouths digest, regurgitate and expel coloured threads, smoke and an egg. The beginning of the video is characterised by a mouth covered by black tape and whose image is reminiscent of the censorship strips used in the scenes of audiovisual productions displaying nudity. Taking the work's subtitle in parenthesis into consideration, what kind of anthropophagy do these mouths in Anna Maria Maiolino's work articulate and materialize? Who devours who or what? Who or what is being devoured in this game? According to the artist, the most evident meaning of In-Out is that of "eating the repressive organs of the dictatorship, the enemies of freedom at that time" (Sileo 149). Maiolino's film is a critical layer in her revisiting of the anthropophagic precept, as a search to find a possible script for a reading and a route in the Brazilian context - especially about the encounter between bodies - enveloped in an atmosphere of repression and constant silencing. As rightly pointed out by Michael Asbury, Maiolino goes a step further when articulating Oswaldian Anthropophagy as a kind of "poetic tool" (75), which goes beyond the mere consideration of anthropophagic premises as elements of representation to finally adopt them as 
founding procedures of several moments of its trajectory.

The play of relations between mouth and oppression, or better, of the challenges of exercising anthropophagic behaviour in limiting contexts, can also be seen in works of the period which do not necessarily seem to articulate an explicit dialogue with Oswaldian Anthropophagy. One example is a scene from the experimental film A Família do Barulho, by Julio Bressane, released in 1970, which presents, in close-up, black ink pouring out of the mouth of the actress Helena Ignez. In this black and white film, which twists Torquato Neto's indications for his Nosferatu in Brazil, one can infer that the ink spouting from the mouth can be read as the vomiting of blood, which happens to the sound of the last movement of Heitor Villa-Lobos' 1958 composition Floresta do Amazonas, sung by the soprano Bidu Sayão. What we are seeing is not exactly swallowing, but the act of returning the internally processed to exterior space which, in this scene from Bressane's film, approaches an abject response to the surrounding hostile context. A second example is the appeal to the tongue, a constitutive musculature of the oral territory and contributor to articulations of discourse. In Língua Apunhalada (Stabbed Tongue), a photographic self-portrait by Lygia Pape created in 1968, the artist presents a tongue that is also shedding blood, becoming an emblematic image of visual criticism of the dictatorship and its oppressive policies of silencing the subject and public space. Pape herself would later defend, in 1980, a Master's dissertation entitled Catiti Catiti, na Terra dos Brasis, about the impact of the "Anthropophagic Manifesto" and the Oswaldian premises on the inventive state of certain artistic practices of the 1960s and 1970s.

The video artist Renata Vater proposes the demystification of the artistic procedure in ARTropophagy, from 1978, presenting herself swallowing the word "art" inscribed on a red balloon that the artist fills up and plays with before devouring. ${ }^{6}$ Renata Vater's mouth is captured by the camera as she chews and devours the deflated "art" balloon and then manipulated by the artist until it becomes the size of her mouth and ready to be tasted. In a direct dialogue with the Oswaldian anthropophagic process, ARTropophagy exposes an artistic process centred on play, manipulation, artifice and resignification of materialities as a form of a critical, and at the same time humorous, response to the adversities suffered by artistic making over the course of these decades, where living/ feeding oneself with art is a challenge and a strategy of constant reinvention.

Lygia Clark also contributed a new layer in approaching anthropophagic thought. Interested in the relationship between art and psychoanalysis at the time, Clark proposed experiences based on the ideas of "body nostalgia" and "body memory," seeking both the dissolution of the art object as well as the (self-)recognition of a plastic and mutant corporeality. The propositions entitled Baba Antropofágica and Canibalismo allude to the Oswaldian imaginary of swallowing, focusing on the movement of swallowing and the gustatory experience as processes of recognition, absorption and resignification of the other. Baba Antropofágica, from 1973, has a direct relationship with bodily fluids, more precisely with saliva, which unfolds from the participants bodies by means of coloured threads extending from their mouths. The threads are supported by the body of one of the participants, who lies on the floor with his eyes closed. The numerous threads end up forming a kind of fabric impregnated with salivary fluxes that "devour" the immobile participant. In fact, there is a tangle of bodies and flows that simultaneously dissolves and constitutes itself as a lived and amorphous corporeality, accessing both a "prospective memory" and a subjectivity removed from identity markers.

The representation of the mouth in the "Anthropophagic Manifesto" is non-existent. What is present are the more general movements of eating and swallowing, the process of which the mouth is a constituent element, as pointed out in this passage: "But they were not crusaders who came. They were fugitives from 
a civilisation that we are eating, because we are strong and vengeful like the Jabuti" (Andrade 134) or the closing passage of the "Manifesto": "Year 374 of Bishop Sardinha's Deglutition" (139). The mouth is not represented precisely because the "Anthropophagic Manifesto" is itself the devouring and articulation of a dissident tongue. In other words, the Oswaldian manifesto materialises as a devouring mouth that transforms the asymmetrical relations of the contents imposed by history. This creative devouring of exteriority, this at once critical and sarcastic swallowing of the outside, as well as of its respective maladjustments, is what seems to constitute the law of the anthropophagic mouth. In this sense, the visual works of Maiolino, Pape, Vater, and Clark seem to swallow the "Manifesto" to turn it into a process of materialization of the mouth as a territory that produces dissidences. The anthropophagic is taken up again, in swallowed form, in order to highlight the hunger for transformation that these artists possessed, starting from the reprocessing of others as a space for the production of subjectivities - in short, an exercise in freedom and expression that local authoritarianism constantly obstructed.

\section{Language-Topography: An Anthropophagic Surrealism?}

In "Schema ao Tristão de Athayde," published in Revista de Antropofagia, Andrade wrote: "We need to revise everything - the language, the right to property, the family, the need for divorceto write as one speaks, maximum sincerity" (3). Starting with language, Andrade sought an anthropophagic dimension therein that would come to provoke significant structural changes, namely in the right to property and the need for divorce. An anthropophagic language would then be an articulation of desire based on a maximum sincerity, in which even writing would be governed by orality. Instead of affirming a national identity, the principles of an anthropophagic language would call it into question, placing it in the fragility of so-called absolute instances, such as the property-family binomial in the context of the birth of a nation. As Maria Carolina Almeida Amaral and Alexandre Nodari stated, what was at stake was "the multiplicity of indigenous peoples and languages, and their agency and historical and current conflicts with whites" (66). Thus, the phrase "tupy or not tupy, that is the question" becomes the rhythm of a linguistic-cosmological diversity, causing the Manifesto to establish a previous surrealism contained in the language itself: "We already had the surrealist language." It is the only mention of the language that neither seeks a regression to claim a program, but projects an inversion of identity politics, whose project aims at a nation. The non-programmatic surrealism of the "Anthropophagic Manifesto" finds in language a heterogeneous topography, not with a people, but proliferated with peoples, uprisings, desires. Once again, anthropophagy dies to be born in other projects. Its effectiveness comes from its erasure, so that the anthropophagic language seems to be clearly inscribed in oral laws that are remembered and followed without the prevailing of what was written. From this point of view, we should not inscribe anthropophagy exclusively in the literal, for fixed in the letter lies its identity trap, but propose it in terms of mobile images that circulate from mouth to tongue. Note that the gesture of showing the tongue has an irreverence, it is a subversive gesture. Thus, the very image and presence of language in works such as those by Pape, Paulo Bruscky, and Lenora de Barros can be read as a variant of the anthropophagic law.

1968 was the year in which the tongue was literally stabbed in Brazil. The military dictatorship was readying itself to strengthen censorship and repression against all and any threat from uprisings and revolts. In the arts, literality was a resource adopted against any symbolic and metaphorical aspect. The tongue occupies a central place in this debate. With Pape's aforementioned photograph Língua Apunhalada, several elements emerge, of which two are worth emphasising here: the "gore," horror, or 
"terrir" in the words of Ivan Cardoso, and the relationship between tongue and ink. The image of the tongue is situated on this threshold: the blood-tongue, which is, on the one hand, the whole previously mentioned cinematographic production of B-movies, science-fiction with a tropical displacement: vampires on the beach, mummies and palm trees, dictators in peripheral nations, and an exacerbation of violence, of crimes of passion on the set of films made with few financial resources. On the other hand, we have the ink-tongue, the relation of a writing that does not materialise, of aborted words, unpublishable texts that end up reinforcing the immanence of the tongue itself in the space where images circulate.

From Pape's image, two other works could be highlighted: Poema, by Lenora de Barros, from 1979, and Poema Linguístico, by Paulo Bruscky, from 1988. In Poema, the letters of a typewriter keyboard encounter the tongue as a surface. Sometimes playing the role of paper (receiving the letters), and sometimes passing over the letters of the keyboard, practically licking it, the tongue occupies the sending and receiving function of a communication that never occurs in the linguistic plane, but rather in an imagetic one. Its presence is self-referential and acts very ambiguously in a sequence of five photographs. This "photoperformance" is inscribed in an "anthropophagic surrealism" detached from the French conception of surrealism, because the Oswaldian emphasis of "anthropophagic" surrealism demands new image ruses, a combat of the tongue against the letter that involves seduction, specific agencying that does not fit European surrealist models. Lenora de Barros's Poema presents a cultural structure between orality and writing through performance techniques that accompany the artist's work in terms of variations. With this, Lenora de Barros explores the limits of [the] tongue. The image of the "stabbed tongue" returns in a frame of the 2012 video Estudo Para Facadas. In a one-minute and thirty-two-second video, the camera focuses on the artist's open mouth, with her tongue visible. The video image suddenly becomes still and at three different moments a knife blade cuts through the image. The blade that cuts the image comes out of the tongue. It is pierced three times. In this "study," the artist promotes the polarity between terror and language by making the image a kind of silent scream whose visual expression converts it into a graphic scream. The artist's action is reminiscent of the "photopoeming" What is Left Over (É O Que Sobra), by Anna Maria Maiolino who, in 1974, used open scissors next to her nose and tongue and suspended the act of cutting with photography. The tongue becomes an object of tension that suprasses metaphors, because it is in the literality of the tongue that artists find a subject that puts it into action.

This is the case with Paulo Bruscky. In Poema Linguístico, Bruscky uses his own tongue as a stamp. With blue ink, a colour marked by administrative insignia, the artist acts upon the surface of paper similar to a form. He produces imperfect stamps, but which leave the traces and marks of his own tongue. The result is a set of marks which, although bearing affinities with Yves Klein's anthropometries, is inscribed in the sphere of a performance on the threshold of bureaucracy (the stamp) and violence (torture). The traces left by the muscle on the page consider the expression of the tongue in its simultaneous muteness and action. An action that is far from rhetorical in terms of an orderly discourse. Therefore, muteness explores the asemantic zones of the tongue that is its own corporeal reality. Considering that much information was obtained by the police from the most diverse methods of torture, a tongue that acts and protagonises an uncertain repetition with the ink of stamps, in the case of Bruscky, and contact between the tip of the tongue against the metal typebars of a typewriter, as occurs with Poema, 1979, by Lenora de Barros. For Lenora de Barros, the tongue is a surface, and it contains a loving duel between the word, in its linguistic and Saussurian sense of "parole": but it should be said that both tongues - and we can include Pape's stabbed tongue here - do not take the word. On the other hand, these tongues expose procedural, poetic aspects, in a clearer dimension, when associated with Roman Jakobson. In an interview 
with the artist, whose background is in linguistics, Lenora de Barros said that Jakobson's "The Functions of Language" was one of the most significant things she had read. Even the concept of "poetic function" is adopted by her as an artistic procedure. In terms of procedure, the physical dimension of language gains autonomy in her photoperformances, turning the mouth into a theatrical space for agrammatical and asemantic agencying in the action of the tongue in the photograph or on paper in the form of a stamp. It is up to the critic to activate the verbal nuclei contained in these images and, through the dimension of the "Anthropophagic Manifesto," a pre-existing surrealist language emerges in Brazil, more archaic and which historically suffered the most diverse violence, including the very act of writing the laws, the rules, the norms, the censors. There is a kind of unwritten law, secret rule, transgressive norm and limited censorship circulating in these images throughout the second half of the 20th century and even into the early two thousands with Lenora de Barros's 2012 video, Estudo Para Facada (Mourão). ${ }^{8}$

\section{Anthropophagy: Death and Birth, Birth and Death. Devouring Against Devotion}

How can Anthropophagy contribute to a reflection on the authoritarianism that plagues contemporary Brazil? It is known that the anthropophagic mouth and tongue were forcibly silenced, once again, by the protagonism of the mouth that spreads insults and the rhetoric of hatred or, in the words of João Cezar de Castro Rocha in Guerra Cultural e Retórica do Ódio, of bocagian verve, unmouthed (68). Furthermore, the gesture of appropriating the value of the enemy instead of eliminating it - a fundamental procedure of the Oswaldian anthropophagic premises - acquires a different configuration if we consider the modus operandi of the current populist and anti-democratic extreme right governments, which appropriate, on the level of discourse and in a twisted way, progressive agendas and their vocabulary.

Perhaps one of the possible answers to the impasse can be found in the revival of an anthropophagic thesis that, according to Raul Bopp, would be discussed during the Brazilian Congress of Anthropophagy, conceived by Andrade to take place on 11th October 1928, but which did not happen. In Vida e Morte da Antropofagia, Bopp argues that the bellow would be a possible system of measurements of the resonance of anthropophagy (73). ${ }^{9}$ The promotion of the anthropophagic bellow, the search for the effective sound vibration and the subsequent measurement of its resonance in the public space can be thought of here as an invitation to the reinvigorated production of the operational discourse of anthropophagy and the hearing of its potency and reach today. The anthropophagic bellow would show itself, therefore, as the vocalisation of a (socially, economically, politically) less favored section of society, far removed from the stability and fixity of the discourses articulated by the official media, which seeks to forge a supposed national identity that imprisons the production of diversity. The bellow would be the vocal response of mouths and tongues that distance themselves from reducible and deterministic processes of knowledge, that refuse the interdict of mutism imposed on them, seeking to propagate, on the other hand, a state of constant mutation at each new engendered devouring. Thus, we seek to show in this study that this devouring occurs in an immanent and figurative order. In Brazil, it has a vast iconography in the proposed selection: from mouth to tongue, from tongue to mouth. Devouring is an inherent quality of the images presented, as each one of them easily and avidly absorbs historical and structural elements of Brazilian culture given from Andrade's manifesto. In this sense devouring is a great technical solution against the devotion of images. Devouring against devotion implies a clash of the images themselves between immanence and transcendence, as mouth and tongue are inscribed as indices of the anthropophagic immanence that reaches the first decades of the 20th century totally committed to this historical and metabolic cycle of Anthropophagy. 


\section{Notes}

1. Towards an approach to the impact of anthropophagy on musical tropicalism, cf. Charles A. Perrone, "Pau-Brasil, Antropofagia, Tropicalismo: The Modernist Legacy of Oswald de Andrade in Brazilian Poetry and Song of the 1960s-1980s." One Hundred Years of Invention: Oswald de Andrade and the Modern Tradition in Latin American Literature, edited by Kenneth David Jackson, Abaporu, 1992, pp. 133-154.

2. Schhiii, woodcut on paper, $66 \times 48 \mathrm{~cm} ; A N N A$, woodcut on paper, $48 \times 66 \mathrm{~cm}$; Glu Glu Glu, woodcut on paper, $66 \times 48 \mathrm{~cm}$.

3. Another comparative approach between the works of Maiolino and Amaral is proposed in Asbury.

4. See www.hauserwirth.com/artists/2833-anna-maria-maiolino.

5. In-Out (Antropofagia). Super-8 Film. Created by Anna Maria Maiolino, with the participation of Eduardo Osório, camera by Sigmund Zehr and sound by Laura Clayton de Souza. Year: 1973/1974. Duration: 08 min $17 \mathrm{sec}$. The film can be seen at vimeo.com/438306054.

6. ARTropophagy. Super-8 Film. Created by Regina Vater and camera by Abraão Berman. Year 1978. Duration 01 min 05 sec. The film can be seen at vimeo.com/298258118.

7. Ivan Cardoso is a director of B movies. He drew upon Brazil's tropical conditions to change the genre configuration of the horror movie, provoking not panic or fear, but laughter in the spectator. An untranslatable pun, "Terrir" is a combination of the Portuguese words for terror (terror) and laughter (rir).

8. The video can be seen at the following link: vimeo.com/lenoradebarros

9. "Some considerations would also be made [at the Brazilian Congress of Anthropophagy] about the bellow, as a system of surface measurements of Anthropophagy. The limits of a given area would be fixed at points, where the last resonances of the bellow could be heard. Not all words have the same radius of penetration in the open air. They differ by the greater or lesser intensity of sound vibration. The official bellower who, to measure an area, syllabulated, in a penetrating high voice, the word 'murucutu' would naturally have a smaller range than with an oxytone on a or $i$ : Taperebá. Ouricuri. The contour of the measurement area would be determined by the points reached by the bellow" (Bopp 73).

\section{Works Cited}

Aguilar, Gonzalo. Por una ciencia del vestigio errático: ensayos sobre la antropofagia de Oswald de Andrade. Grumo, 2010.

Andrade, Oswald de. "Manifesto Antropófago." Vida e morte da Antropofagia, edited by Raul Bopp, José Olympio, 2008, pp. 127-139.

. “A psicologia antropofágica.” Os dentes do dragão, by Oswald de Andrade, Globo, 1990, pp. 18-55.

" "Schema ao Tristão de Athayde." Revista de Antropofagia, no. 5, Sept. 1928, p. 3.

Amaral, Maria Carolina Almeida, and Alexandre Nodari. "A questão (indígena) do 'Manifesto Antropófago." Antropofagias: um livro manifesto! Práticas da devoração a partir de Oswald de Andrade, edited by Pauline Bachmann, et al., Peter Lang, 2021, pp. 57-83.

Asbury, Michael. "Anna Maria Maiolino: Articulations and Translations of and in Anthropophagy." Anna Maria Maiolino: Making Love Revolutionary, edited by Lydia Yee and Trinidad Fombella, Whitechapel Gallery, 2019, pp. 69-76.

Bopp, Raul, editor. Vida e morte da Antropofagia. José Olympio, 2008.

Campos, Augusto de. Balanço da Bossa. Perspectiva, 1974.

Castro Rocha, João Cezar de. Guerra cultural e retórica do ódio: crônicas de um Brasil pós-político. Caminhos, 2021.

—. "Uma teoria de exportação? ou: Antropofagia como visão do mundo." Antropofagia hoje? Oswald em cena, edited by Jorge Ruffinelli and João Cezar de Castro Rocha, É Realizações, 2011, pp. 647-668.

Clark, Lygia. "Da supressão do objeto (anotações)." Escritos de artistas anos 60/70, edited by Glória Ferreira e Cecília Cotrim, Zahar, 2006, pp. 350-356.

Harvey, John J. “Cannibals, Mutants, and Hipsters: The Tropicalist Revival.” Brazilian Popular Music \& Globalization, edited by Christopher Dunn and Charles Perrone, Routledge, 2001, pp. 106-122.

Jackson, Kenneth David. "Novas receitas da cozinha canibal: o Manifesto Antropófago hoje." Antropofagia hoje? Oswald em cena, edited by Jorge Ruffinelli and João Cezar de Castro Rocha, É Realizações, 2011, pp. 429-453.

Mourão, Raul. Jacarandá: Journal of Brazilian Art and Beyond. Funarte, 2015.

Sileo, Diego. "Anna and I: Anna Maria Maiolino in Conversation with Diego Sileo.” Anna Maria Maiolino: Making Love Revolutionary, edited by Lydia Yee and Trinidad Fombella, Whitechapel Gallery, 2019, pp. 145-156. 